\title{
Improving population estimates of Swedish birds using the Breeding Bird Survey fixed routes and correction factors from Finnish line transect surveys
}

\author{
Förbättring av populationsskattningar av svenska fåglar med hjälp av Svensk \\ Fågeltaxerings fasta rutter och korrektionsfaktorer från finska linjetaxeringar
}

\author{
SÖREN SVENSSON
}

I estimated population size of fifty-nine common birds by
using the fixed routes of the Swedish Bird Survey (SBS),
which give the number of birds per kilometer. I converted
this number to density, birds $/ \mathrm{km}^{2}$, using the correction
factors for detectability that have been developed for line
transects in Finland. I compared the population estimates
by this new method with those in a previous account
from 2012 , in which the estimates of common birds were
primarily based on extrapolation of habitat-specific den-
sities from numerous territory mapping plots. There was
good agreement for the most abundant species but a clear
tendency that the estimates with the new method were

\section{Abstract}

higher for many less common ones. As little new density data are being collected, the SBS fixed routes are likely to be the prime source of data for future national population estimates. Although the Finnish correction factors can be used to improve the Swedish estimates for suitable species it is advisable to develop factors specifically adapted to the Swedish counts for application to a wider spectrum of species.

Sören Svensson, Department of Biology, Biodiversity, University of Lund, 22362 Lund, Sweden. E-mail: Soren. Svensson@biol.lu.se

Received 29 August 2016, Accepted 17 October 2016, Editor: Å. Lindström

\section{Introduction}

How many pairs of breeding birds are there? The question is asked not only by population and community scientists or by curious laymen. Increasingly, it is asked by governmental bodies at different levels from perspectives of conservation, management or legislation. For example, the Swedish Environmental Protection Agency (SEPA) contracts collection of bird population data, partly for its own use within the country, partly because it is required to report to the European Union for compilation of environmental indicators. One example where Swedish data have contributed is the assessment of how strategic conservation measures within the EU Common Agricultural Policy have affected birds (Gamero et al. 2016). Concern about bird populations has often been a part of the rationale for different international conventions: Bern (habitats), Bonn (migratory species) and Ramsar (wetland) conventions and Convention on Biological Diversity (Nagoya protocol, ratified by Sweden 2016). But there are no firm requirements about reporting national population estimates. Within the European Union the Birds Directive (2009/147/EC) is a core document. Recently an important addition has been enforced. It is now required by all member states to report absolute population size of all wild birds.

There are also non-governmental organizations that need absolute population estimates, for example the International Union for Conservation of Nature for the so called red lists of endangered birds (www.iucnredlist.org). One of several regional lists is the one compiled by BirdLife International (2015) for Europe. In Sweden a national list is published every five years, the most recent one in 2015 (Artdatabanken 2015). Categorization of the bird species into different threat categories requires detailed information on both trends and absolute numbers.

There have been four efforts to estimate the population size of all bird species breeding in Sweden: Ulfstrand \& Högstedt (1976), Koskimies (1993), Asbirk et al. (1997) and Ottosson et al. (2012). In Ottosson et al. (2012) the estimates for common species were based on habitat-specific densities multiplied by the national area of each habitat. For less common and rare species other methods were used, primarily a careful search of all literature, 
both regional and national. For a small number of species with very little information available "educated guesses" were made, for example by comparing with similar species with better known status. The vast majority of habitat-specific density values emanated from territory mapping plots that were surveyed in the period 1970-1990 and apart from more recent surveys of farmland, few estimates of true densities have been made after 1990. Details are given in Ottosson et al. (2012).

In 1996, a new national scheme for monitoring population trends was launched as part of the Swedish Bird Survey (SBS; Svensson 1996, 2000; Lindström et al. 2007). Before 1996 trends were based on territory mapping plots and point counts at sites chosen by volunteers, which were rather non-representative with respect to both geography and habitats. The new scheme was designed to provide data representative for different habitats and geographical regions, and it has been the main instrument for population trend monitoring since then (Green \& Lindström 2015). Seven hundred and sixteen fixed survey routes are distributed systematically over all Sweden, twenty-five kilometers apart in both south-north and west-east directions. Each route comprises eight one-kilometer line transects and eight five minute point counts in between each. The routes are surveyed once a year during a three-week period adapted to local phenology to capture as many species as possible, starting on 15 May in the south and on 15 June, or later if necessary, in the northern mountains. A survey of a fixed route always starts at four o'clock in the morning and lasts five to seven hours. All bird individuals heard or seen are recorded, independent of distance, and excluding only downy young, unfledged nestlings, and obvious double counts between adjacent line kilometer sections.

Line transects have long been used in Finland. The Finnish method (Koskimies \& Väisänen 1991) differs in three respects from the Swedish fixed routes. First, the count unit in Finland is a pair equivalent (one male, one female, one pair or one brood without parent) instead of an individual bird. Second, observations are recorded separately for two zones, within and beyond twenty-five meters on both sides of the transect line. The zones are called the main belt and the supplementary belt, together making up the survey belt; the latter corresponds to the belt without limits (and hence without defined area) used in the Swedish fixed routes. The proportion of records within twenty-five meters can be used as a measure of lateral detectability as demonstrated in a series of papers (Järvinen \& Väisänen
1975, 1976a, 1976b; Järvinen 1976, 1978; Järvinen et al. 1976, 1977). Counts of birds with strong and far-reaching calls will show a lower proportion of records closer than twenty-five meters than birds with weak calls. This makes it possible to calculate species-specific detectability factors that can be used to make the counts of different species comparable. This detectability is called lateral detectability as distinguished from basal detectability which tries to correct also for birds that are not at all detected, not even close to the transect line. Lateral detectability correction factors were first published by Järvinen \& Väisänen (1983) and recently new factors were published by Lehikoinen et al. (2014). Factors correcting for basal detectability have been published by Rajasärkkä (2010). A third difference is walking speed. The line transects of the Swedish fixed routes are walked with a speed of one kilometer per 30-45 minutes, mainly adapted to how difficult the terrain along the route is. The Finnish transects are walked with a speed of 45-60 minutes per kilometer. A Finnish route thus takes more time because the observer is required to estimate the distance to each bird and to put down its position on a map together with habitat information.

It is comparatively easy to monitor national temporal trends of breeding bird species populations. It is sufficient to determine a geographically representative relative measure, an index, which is comparable from year to year. This goal can be achieved, without any knowledge of absolute density, by counting birds with the same standard method every year at a selection of statistically representative sample sites. The fixed routes of the Swedish Bird Survey provide such an index.

Absolute population size is more difficult to determine. There are two alternatives. The first is to determine the absolute numbers in a set of representative sample plots of known size. This will produce density values that, with appropriate precautions, can be extrapolated to the whole country. The second alternative is to use a suitable density index and convert it to density by an experimentally determined correction factor. The Swedish Bird Survey provides such an index for all species, the number of individual birds recorded per kilometer line transect.

The purpose of this paper is twofold. First, I intend to calculate better national estimates than before for a selection of species that I believe are particularly suitable by using the Finnish correction factors (Rajasärkkä 2010, Lehikoinen et al. 2014) to convert the SBS density indices to absolute densities. These new estimates will be compared with 
those of Ottosson et al. (2012). Second, I provide some ideas on how to develop correction factors that are better adapted to the SBS counts than the ones from Finland and that would allow conversion of SBS indices to densities with greater precision and for a larger number of species.

\section{Methods}

To account for the fact that the unit of a Finnish line transect count is a pair equivalent rather than an individual bird, I selected species in which the SBS records are mainly singing males. A singing male represents a pair and if the proportion of singing males among all records is high, a count of individuals becomes a good representation of the number of pairs. A majority of the territorial songbirds in northern Europe belongs to this category. To these passerines I added six woodpeckers and the Cuckoo, assuming that they have territorial systems and calling behaviors similar to those of the passerines. In total, fifty-nine species were included. In sheer numbers, these species represent more than $80 \%$ of all breeding pairs in Sweden according to Ottosson et al. (2012). In order to provide further support for the assumption that most fixed route records for these fifty-nine species are pair equivalents, I examined 220,000 five-minute point counts. If most records during a point count were records of a single individual, hence a pair equivalent, most records along a line transect also ought to be pair equivalents. Species with more than $85 \%$ such single individual records are marked with an asterisk in Table 1. My assumption is that virtually all fixed route records of the selected fifty-nine species represent pair equivalents and that no correction for this potential bias is necessary.

I used the line transect values given in table A2, pp. 552-556 in Ottosson et al. (2012) as the Swedish sample. These values were based on all fixed routes surveyed during the period 1996-2010 and they represent average values from 4920 eight kilometer surveys and hence a total of 39,360 kilometers of line transect. As these values showed the number of birds per route (eight kilometers), I recalculated them to birds per kilometer. The number of records per kilometer fixed route was first multiplied with the correction factors for lateral detectability in column KK or KE in table 2 in Lehikoinen et al. (2014). As the correction factors differed between northern and southern Finland (higher in the south) and as a large part of Sweden is located south of Finland, I used the values for southern Finland (column KE) for species with mainly a southerly distribution in Sweden; for the other species the value for all Finland (column KK) was used. For correction of basal detectability, I then multiplied with the values of column $\mathrm{T}$ in table 1 in Rajasärkkä (2010). This gave an estimate of pairs/ $\mathrm{km}^{2}$. Finally, I multiplied this density estimate with the total area of Sweden, $450000 \mathrm{~km}^{2}$.

The nomenclature follows Ottosson et al. (2012) and the English, scientific and Swedish names of birds are found in Table 1. Elsewhere in the paper I use the shorter versions of the English names or, in the figures, the scientific names.

\section{Results}

National population estimates based on the line transect counts after multiplication with both the lateral and basal correction factors are shown in Table 1, together with the estimates in Ottosson et al. (2012). Several interesting comparisons can be made from the two datasets.

However, I first compared the abundance rank of the species according to the raw number of birds per kilometer fixed route with the rank after correction for only lateral detectability (Figure 1). The horizontal bars show how much the rank has shifted, been up- or down-graded, after lateral correction. The two most numerous species (Willow Warbler and Chaffinch) and the two least numerous ones (Golden Oriole and Red-breasted Flycatcher) obtain exactly the same position before and after correction. Among the remaining species, only six end up in exactly the same position. However, minor position shifts tell little of interest as they are not independent but mutually affecting each other. And it is likely that the shifts among the least common species are more error-prone than those among the common species. It is therefore the large deviations among more common species that are of greatest interest. The largest shifts to a lower rank are found for Brambling (shifting from position 3 for raw data to position 8 after lateral detectability correction, 5 positions down), Song Thrush (6 to 10, 4 down), Redstart (10 to 20, 10 down), Cuckoo (15 to 39, 24 down), and Black Woodpecker (34 to 43, 9 down). Large shifts in the opposite direction are found in Great Tit ( 9 to 4, 5 up), Goldcrest (11 to 6, 5 up), Spotted Flycatcher (19 to 11, 8 up), Blue Tit (22 to 13, 9 up), White Wagtail (23 to 12, 11 up), Willow Tit (24 to 18, 6 up), and Treecreeper (35 to 28,7 up). The number of shifts in the different directions is almost the same, 23 and 26 respectively, with 10 species remaining in the same position. 
Table 1. Estimated breeding populations of birds in Sweden according to line transect count data from the Breeding Bird Survey, transformed to national population size by detectability-correction factors developed in Finland (Lehikoinen et al. 2014, Rajasärkkä 2010), versus estimates in Ottosson et al. (2012). An asterisk denotes a species with more than $85 \%$ single individual records during five minute point counts (see text).

Beståndsskattningar för fåglar enligt data från Svensk Fågeltaxerings linjetaxeringar, vilka omräknats med faktorer för observerbarhet (Lehikoinen et al. 2014, Rajasärkkä 2010), i förhållande till skattningar i Ottosson et al. (2012). En asterisk anger att arten $i$ 85\% av alla fem-minuters punkttaxeringar registreras med bara en individ (se text).

\begin{tabular}{|c|c|c|c|c|}
\hline English name & Scientific name & Swedish name & $\begin{array}{r}\text { Corrected line } \\
\text { transects } \\
\end{array}$ & $\begin{array}{r}\text { Ottosson et al. } \\
(2012) \\
\end{array}$ \\
\hline Willow Warbler & Phylloscopus trochilus & Lövsångare & 12000000 & 13000000 \\
\hline Common Chaffinch & Fringilla coelebs & Bofink & 9200000 & 8400000 \\
\hline European Robin & Erithacus rubecula & Rödhake & 3300000 & 3800000 \\
\hline Great Tit & Parus major & Talgoxe & 3300000 & 2600000 \\
\hline Goldcrest & Regulus regulus & Kungsfågel & 2700000 & 3000000 \\
\hline Tree Pipit & Anthus trivialis & Trädpiplärka & 2600000 & 2400000 \\
\hline Brambling & Fringilla montifringilla & Bergfink & 2200000 & 2100000 \\
\hline Common Blackbird & Turdus merula & Koltrast & 2200000 & 1800000 \\
\hline Redwing & Turdus iliacus & Rödvingetrast & 1800000 & 1100000 \\
\hline Spotted Flycatcher & Muscicapa striata & Grå flugsnappare & 1800000 & 1500000 \\
\hline Song Thrush & Turdus philomelos & Taltrast & 1500000 & 1900000 \\
\hline Eurasian Blue Tit & Cyanistes caeruleus & Blåmes & 1400000 & 700000 \\
\hline White Wagtail & Motacilla alba & Sädesärla & 1400000 & 410000 \\
\hline Yellowhammer & Emberiza citrinella & Gulsparv & 1200000 & 900000 \\
\hline Eurasian Blackcap & Sylvia atricapilla* & Svarthätta & 1100000 & 1200000 \\
\hline Garden Warbler & Sylvia borin* & Trädgårdssångare & 1000000 & 1200000 \\
\hline European Pied Flycatcher & Ficedula hypoleuca & Svartvit flugsnappare & 980000 & 1400000 \\
\hline Willow Tit & Poecile montanus & Talltita & 968852 & 800000 \\
\hline European Greenfinch & Chloris chloris & Grönfink & 950000 & 660000 \\
\hline Eurasian Wren & Troglodytes troglodytes & Gärdsmyg & 740000 & 500000 \\
\hline Common Redstart & Phoenicurus phoenicurus* & Rödstjärt & 700000 & 900000 \\
\hline Whinchat & Saxicola rubetra & Buskskvätta & 670000 & 250000 \\
\hline Gr. Spotted Woodpecker & Dendrocopos major* & Större hackspett & 630000 & 210000 \\
\hline Common Whitethroat & Sylvia communis & Törnsångare & 600000 & 250000 \\
\hline Dunnock & Prunella modularis* & Järnsparv & 570000 & 630000 \\
\hline European Crested Tit & Lophophanes cristatus & Tofsmes & 530000 & 400000 \\
\hline Eurasian Treecreeper & Certhia familiaris* & Trädkrypare & 420000 & 750000 \\
\hline Common Reed Bunting & Emberiza schoeniclus & Sävsparv & 400000 & 400000 \\
\hline Coal Tit & Periparus ater* & Svartmes & 390000 & 410000 \\
\hline Lesser Whitethroat & Sylvia curruca* & Ärtsångare & 330000 & 250000 \\
\hline Wood Warbler & Phylloscopus sibilatrix & Grönsångare & 300000 & 220000 \\
\hline Mistle Thrush & Turdus viscivorus* & Dubbeltrast & 280000 & 330000 \\
\hline Common Chiffchaff & Phylloscopus collybita* & Gransångare & 200000 & 190000 \\
\hline Red-backed Shrike & Lanius collurio* & Törnskata & 190000 & 44000 \\
\hline Rustic Bunting & Emberiza rustica* & Videsparv & 180000 & 40000 \\
\hline Bluethroat & Luscinia svecica* & Blåhake & 150000 & 230000 \\
\hline Icterine Warbler & Hippolais icterina* & Härmsångare & 130000 & 50000 \\
\hline Marsh Warbler & Acrocephalus palustris & Kärrsångare & 130000 & 24000 \\
\hline Common Cuckoo & Cuculus canorus* & Gök & 94000 & 78000 \\
\hline Sedge Warbler & Acrocephalus schoenobaenus & Sävsångare & 76000 & 100000 \\
\hline
\end{tabular}




\begin{tabular}{lllrr} 
Thrush Nightingale & Luscinia luscinia & Näktergal & 72000 & 37000 \\
Grey-headed Chickadee & Poecile cinctus & Lappmes & 71000 & 54000 \\
Black Woodpecker & Dryocopus martius* & Spillkråka & 59000 & 29000 \\
Snow Bunting & Plectrophenax nivalis & Snösparv & 57000 & 26000 \\
Eurasian Three-toed Woodpecker & Picoides tridactylus* & Tretåig hackspett & 55000 & 11000 \\
Eurasian Reed Warbler & Acrocephalus scirpaceus & Rörsångare & 53000 & 290000 \\
Common Rosefinch & Carpodacus erythrinus* & Rosenfink & 33000 & 17000 \\
Hawfinch & Coccothraustes coccothraustes & Stenknäck & 33000 & 17000 \\
Ortolan Bunting & Emberiza hortulana & Ortolansparv & 27000 & 6300 \\
Eurasian Wryneck & Jynx torquilla & Göktyta & 26000 & 25000 \\
Pine Grosbeak & Pinicola enucleator & Tallbit & 24000 & 10000 \\
Le. Spotted Woodpecker & Dendrocopus minor* & Mindre hackspett & 20000 & 7000 \\
Woodlark & Lulula arborea* & Trädlärka & 19000 & 15000 \\
Ring Ouzel & Turdus torquatus & Ringtrast & 14000 & 6200 \\
Great Grey Shrike & Lanius excubitor* & Varfågel & 11000 & 6000 \\
Grey-headed Woodpecker & Picus canus* & Gråspett & 7400 & 1900 \\
Grashopper Warbler & Locustella naevia* & Gräshoppsångare & 6700 & 4600 \\
Red-breasted Flycatcher & Ficedula parva* & Mi. flugsnappare & 3900 & 1100 \\
Eurasian Golden Oriole & Oriolus oriolus* & Sommargylling & 560 & 120 \\
\hline
\end{tabular}

Figure 1. The shift of abundance rank from the rank a species had according to the raw data from the Swedish Bird Survey (birds $/ \mathrm{km}$ ) to the rank it obtained after multiplication with Finnish correction factors for lateral detectability. For example, the Cuckoo Cuculus canorus with far-reaching calls has moved 24 steps down in rank and the modest Spotted Flycatcher Muscicapa striata 8 steps up in rank. The species that did not shift rank have no bars. In the diagram the most common species at top, the least common at bottom.

Förändringen $i$ rangordning från den position en art hade enligt rådata från Svensk Fågeltaxering (individer $/ \mathrm{km}$ ) till den position den fick efter multiplikation med finska korrektionsfaktorer för lateral observerbarhet. Till exempel flyttas göken med sin ljudliga stämma 24 steg ner $i$ rangordning medan den mera diskreta grå flugsnapparen flyttas upp 8 positioner. Arter som inte bytte position saknar stapel. I diagrammet står de vanligaste arterna överst och de fåtaligaste nederst.

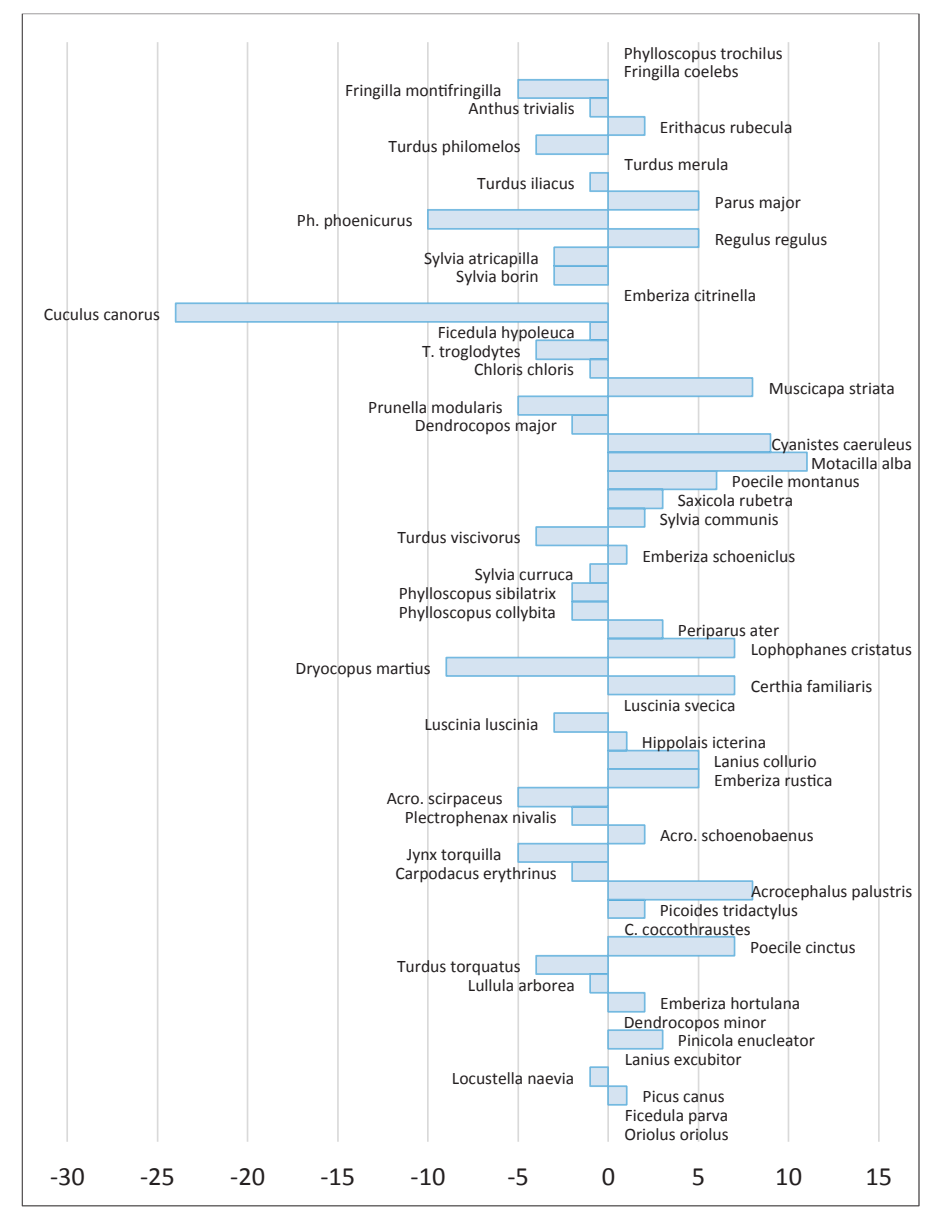




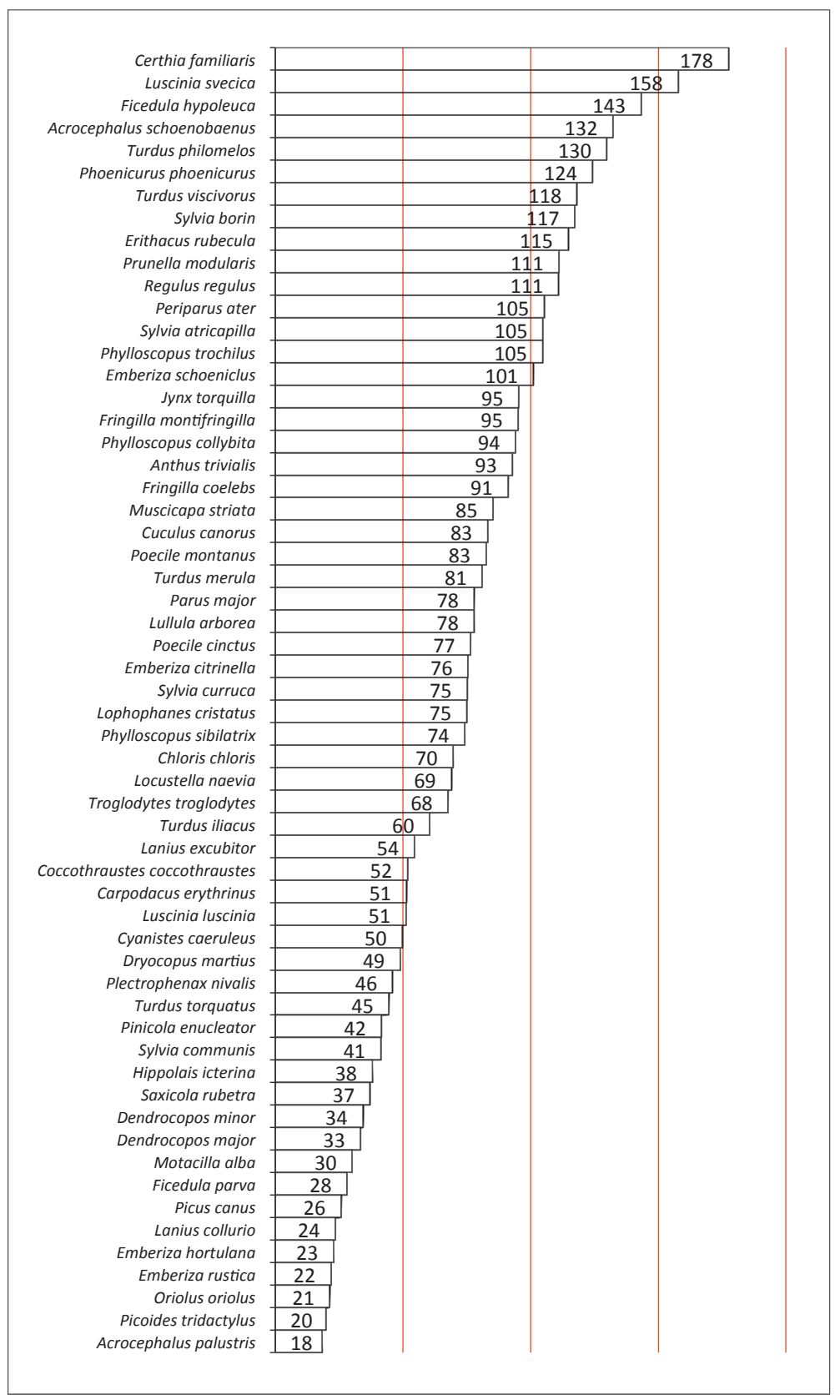

Figure 2. National breeding population estimates for Sweden in Ottosson et al. (2012) as a percentage of the new estimates based on detectability-corrected line transect counts of the Swedish Bird Survey. For example, the estimate of Treecreeper Certhia familaris was 750,000 pairs in Ottosson et al. (2012) and 420,000 pairs with the detectability-corrected method (this study), where the first estimate is $178 \%$ of the latter. Reed Warbler Acrocephalus scirpaceus $(549 \%)$ is omitted from the diagram.

Beståndsuppskattningarna för Sverige enligt Ottosson et al. (2012) $i$ procent av de nya skattningarna baserade på linjetaxeringarna $i$ Svensk Fågeltaxering efter korrigering medfinskadetektabilitetsfaktorer (denna studie). Till exempel hade trädkryparen en beståndsskattning på 750.000 par i Ottosson et al. (2012) och 420.000 par efter korrigering för detektabilitet (denna studie), och det förstnämnda värdet är $178 \%$ av det senare. Rörsångaren (549\%) har uteslutits från diagrammet.

The national population estimate in Ottosson et al. (2012) is higher than the estimate based on corrected line transect values in sixteen species and lower in the remaining 43 species (Table 1, Figure 2). In one species, the Reed Warbler, the estimate in Ottosson et al. (2012) is very much higher (290,000 vs. 53,000 pairs, $543 \%$ higher). A related species, the Sedge Warbler, has a much lower value, only $132 \%(97,000$ vs 71,000$)$. Between these species fall the Treecreeper, Bluethroat and Pied Flycatcher (about 1.5 times higher). There are 40 species for which the estimate in Ottosson et al. (2012) falls in the region $50 \%-200 \%$ of the corrected line transect estimate, i.e. half or twice in 


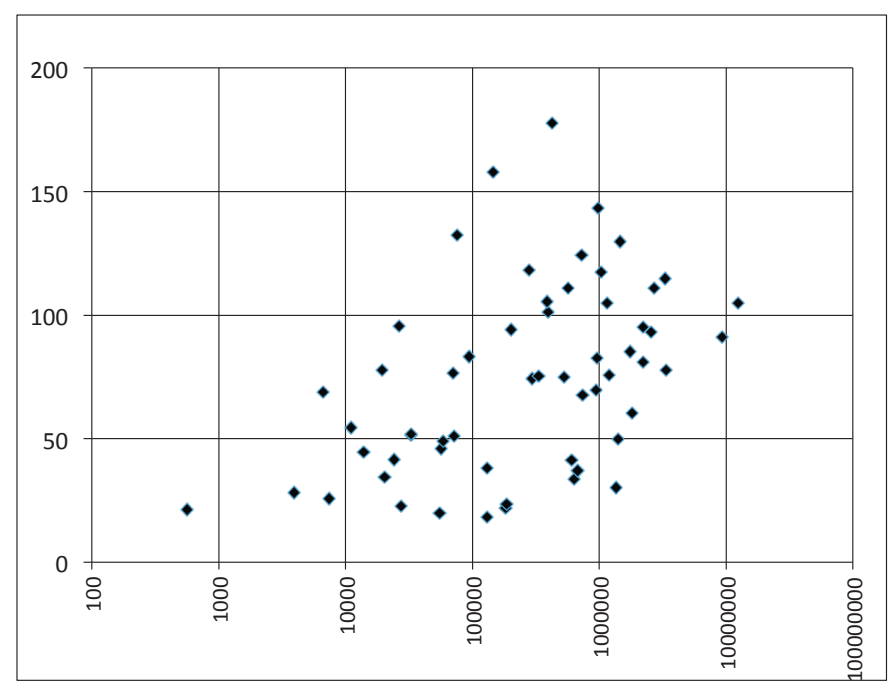

Figure 3 . The percentage difference between estimates in Ottosson et al. (2012) and estimates based on detectability-corrected line transect data from the Swedish Bird Survey (y axis) in relation to total abundance (x axis). Acrocephalus scirpaceus (549\%) was excluded from the diagram.

Procentuella skillnaden mellan skattningarna I Ottosson et al. (2012) och skattningarna baserade på de korrigerade värdena från Svensk Fågeltaxering (y-axeln) $i$ förhållande till artens beståndsstorlek ( $x$-axeln). Rörsångaren (549\%) är ej medtagen $i$ diagrammet.

numbers. Within the narrow range of $75 \%$ to $125 \%$ there are 25 species. For as many as 18 species, though, the estimate in the Ottosson et al. (2012) is below $50 \%$ of the corrected values calculated here. Among all 59 species, $43(73 \%)$ had lower estimates in Ottosson et al. (2012). Thus, there is a strong bias towards underestimates in Ottosson et al. (2012) compared to values based on the SBS line transect values corrected for detectability.

The frequency and size of these underestimates differ depending on how common a species is (Table 1, Figure 3). For species with less than 100,000 pairs, 19 out of 21 species $(90 \%)$ are lower, and for more common birds the corresponding figures are: $100,000-1,000,000$ pairs, 14 of 22 species (64\%); $>1,000,000$ pairs, 10 of 16 species $(62 \%)$.

For the fifty-nine species together the Ottosson et al. (2012) estimate is 56 million pairs, whereas that based on detectability-corrected line transects is 60 million pairs. The small difference between these totals is mainly due to the fact that the estimates of the two most abundant species are very similar.

\section{Discussion}

There is no doubt about the demand of quantitative information about bird populations. As mentioned in the introduction Sweden is required to report that information to EU according to the Birds Directive. The question is only how precise it must be. But for one purpose, exact numerical values are required, namely for assessing the threat level of a species in the IUCN Red list of threatened species.
For example, Sweden applies a limit of less than 500 pairs for a non-declining and 5000 pairs for a declining species to be included among the threatened species (i.e. at least "vulnerable"). In Sweden the red list has a high degree of authority as it is adopted, on behalf of the government, as an official document by the SEPA and also used as such by county administrative boards and municipal governments.

Most species included in this paper are rather abundant and not candidates for red-listing on the basis of their population size only. But if accurate correction factors for all species in Sweden could be developed, the SBS line transects would be an excellent instrument for precise estimates of population size of many species, even quite rare ones.

\section{Do the Finnish correction factors work in Sweden?}

There are several difficulties involved in using the line transect counts as so many confounding factors are involved, for example habitat, geographical region, date, community and species density, weather, phenology, and observer skill. Standardization can only partly compensate for these possible biases. The potential sources of error in bird counts have been discussed numerous times during the history of bird surveys, for example by Enemar (1959). The Finnish correction factors are of course liable to the same difficulties, and they were discussed and analysed by Järvinen and Väisänen in their many papers referred to above. Clearly, errors, variation and bias may emanate from both the 
Swedish line transect counts and from the Finnish correction factors.

One important question is whether the Finnish correction factors can be applied in all of Sweden. Sweden and Finland differ in some respects. For example, a large part of Sweden is located south of Finland and a larger proportion of northern Sweden is montane. But in spite of these differences the features of the predominant vegetation type in both countries, commercial forest, are similar. This means that there is only little a priori expectation that the use the Finnish corrections should give drastically misleading results.

The correction factors in Lehikoinen et al. (2014) are different between southern and northern Finland. The average for southern Finland was 4.6 and for northern Finland 5.4 (calculated for the 42 species with values for both parts of Finland). It is difficult to judge how different the estimates would be if correction factors existed for southern Sweden. I made the calculations both with and without the separate correction factors for southern Finland, but the differences were marginal. This may indicate that special factors for southern Sweden would not make much difference. However, as demonstrated by Järvinen \& Väisänen (1983) total density of the community affects the species estimates by affecting detectability. As total density is lower in the north and higher in the south, northern species tend to be underestimated and southern species overestimated. In Finland, one therefore also corrects for this latitudinal effect (Virkkala \& Lehikoinen 2014). This correction cannot be applied in Sweden because it requires main belt densities which are not available. Hence, this is one argument for developing specifically Swedish conversion factors.

The correction factors for basal detectability (Rajasärkkä 2010) differed very little among species (1.4-1.7, with an average value of 1.53). This moderate variation is what one would expect since the large variation in lateral detectability has already been removed. Ideally, the correction factor should be determined by carrying out line transects in plots with well-known densities of all relevant species. Two such studies have been carried out in very small plots with uncertain results (Järvinen et al. 1978a,b). A third study made by Tiainen et al. (1980) was larger in scope and intended to better represent the mixture and proportion of different habitats normally included in a Finnish line transect. In this case the basal detectability was $65 \%$, which corresponds well with the value of about 1.5 for correction of basal detectability (Rajasärkkä
2010). A single visit in a territory mapping plot is approximately comparable in efficiency to a line transect in such a plot. For example, Enemar (1959) found that single visits showed an average detectability of $60 \%$ for 15 species, and a detectability of $71 \%$ for the four species with the largest samples. This also suggests a multiplication factor of about 1.5 for basal detectability.

\section{Shifts in abundance rank}

The shifts of position in the abundance sequence after lateral correction in Figure 1 are largely the expected ones, namely that species with far-reaching calls and hence a large proportion of records beyond twenty-five meters get a lower rank, whereas secretive and less far-sounding species get a higher rank. Obvious examples are Songtrush, Redstart, Cuckoo and Black Woodpecker (downgraded) and Treecreeper, White Wagtail, Blue Tit, Spotted Flycatcher, and Goldcrest (upgraded). However, it is meaningless to discuss details in the movements of the species along the relative abundance gradient because the ranks depend on each other. For the purpose of this paper I simply accept that the lateral corrections removed most of the differences in lateral detectability.

Note, however, that a large shift in abundance rank does not always imply a large shift in abundance estimate. For example, the Reed Warbler moved only from position 41 to 46 after correction which may seem little, but in number of pairs from 290,000 in Ottosson et al. (2012) to 53,000 based on corrected line transects. This difference is beyond easily explained errors. It is unlikely that the correction factor for lateral detectability is remarkably wrong as it lies in the same range as for a number of warblers. A possible explanation may rather be that the fixed route counts severely underestimate the Reed Warbler because observers walk to the side of the very wet reed habitats thus obtaining a much too low count. The more terrestrial Sedge Warbler is less likely to be unintentionally avoided, but also because it has prominent display flight that can be observed at considerable distance.

The Cuckoo showed a pattern opposite to that of the Reed Warbler. It shifted rank from 14 to 39 after lateral correction, a large shift, but very little in numerical estimates, only from 78,000 to 100,000 . This is well within the acceptable estimation error and possibly also within normal between-year population size fluctuation. 


\section{Why different estimates}

Why are a majority of the estimates by Ottosson et al. (2012) lower than the corrected line transect estimates (Figure 3)? And why is this tendency particularly evident for species with less than one hundred thousand pairs, for which ninety percent show lower estimates? For the two most abundant species there is almost no difference at all. It is expected that the difference between the two methods should increase with declining species abundance as both the amount of density data and sample size for calculation of correction factors decline. However, it was not expected that so many of the less abundant species were to obtain so consistently lower estimates.

The explanation for the agreement between the estimates by the two methods for the commonest species is most probably the fact that very representative density data were available to Ottosson et al. (2012). Most of the abundant species are distributed over large parts of Sweden and in several different habitats, and high quality density estimates from many plots representing all habitats and all parts of the country were available; good trend data for most of the species were also available, so it was possible to adjust the density estimates accordingly for the few species that had changed much in recent years. As the amount of density estimates became scarce with decreasing abundance and distribution of the species the estimates in Ottosson et al. (2012) are expected to turn less reliable.

Another explanation for why estimates in Ottosson et al. (2012) tend to be conservative relative the corrected line transect estimates for less common species could be that the factors for lateral detectability correction are biased in relation to bird abundance. But there is absolutely no deviation from zero slope when the KK values in Lehikoinen et al. (2014) are correlated with population size in Finland.

A likely explanation for many low estimates in Ottosson et al. (2012) is that the authors were deliberately conservative, and more so the less common the species is. The less common a species, the fewer reliable habitat-specific density estimates were available for the population size calculations and the more they had to trust their general opinion about which density values to apply. They were probably affected by a general caution not to overestimate population size. The Precautionary Principle has not been a silent part of the EU or national legislation but has had a profound influence and has permeated thinking and attitudes in nature conservation; best to be on the safe side in the face of possible threats to a species. Additionally, to be conservative is probably an inherent psychological property among ornithologists; for example, when judging the size of a flock or reporting the number of birds after a sweep with the binoculars, one tends to say "at least one hundred" rather than "less than one thousand".

A comparable study in the UK (Newson et al. 2008) arrived at exactly the same pattern as I have found. They compared population estimates based on habitat-specific densities multiplied with habitat area and detectability-corrected line transect counts. One study was based on the plots of the Common Birds Census (CBC). The CBC used plots where the number of breeding pairs was determined by mapping their territories during several visits distributed over the entire breeding season. The total UK population estimates were then obtained by extrapolation of the densities in relation to the extent of each habitat. The other study was based on the line transects of the British Breeding Bird Survey (BBS). In the BBS the observers counted all birds along a $2 \mathrm{~km}$ long transect, one in each of 2500 sites distributed in a stratified random manner all over the UK. The counts were of individuals, not of pairs, and the count was repeated twice a year. The early count was used for residents and the late count for migrants. The distance to all birds was determined with a precision of $0-25$, 25-100 and beyond 100 meters. The population estimates were then calculated with a standard program for distance sampling (DISTANCE 5.0) and divided by two to transform number of individuals to number of pairs. Hence, BBS is similar to the Swedish fixed route counts in counting individuals, not pairs, and similar to the Finnish line transects in making distance estimates ( $0-25$ and beyond 25 meters in Finland). Newson et al. (2008) found that for the most common species the population estimates from $\mathrm{CBC}$ and BBS data were similar. For 28 species with more than one million pairs according to $\mathrm{CBC}$, the BBS estimates were almost equally distributed about the line of equivalence (13 higher, 15 lower). For species with less than one million pairs the BBS estimates were most often higher than the $\mathrm{CBC}$ estimates, and for the very least common species, those with less than one hundred thousand UK pairs according to the CBC estimate, 24 of 29 had higher BBS estimates. Although the line transect counts were corrected by different methods, the differences were the same: the corrected line transects produced higher estimates than habitat-specific densities. Newson et 
al. (2008) could not explain why the line transects tended to produce higher estimates than the mapping plots, and concluded that there is no way of telling which of the estimates (CBC or BBS) are the correct ones. As a remedy they suggest "to carefully design independent surveys for carefully chosen species that would provide the most reliable baseline for comparison."

\section{A few species as examples}

Even taking all the various effects and suggested explanations into consideration, some of the differences between the estimates in Ottosson et al. (2012) and the corrected SBS counts are remarkable. For example, the corrected estimates for Redbacked Shrike and Rustic Bunting are five times higher, about 200,000 versus 40,000 pairs, than those of Ottosson et al. (2012) (Table 1). Similarly, the number of Marsh Warblers is five times higher (more than 100,000 versus 20,000 pairs). Interestingly, the estimates for all three woodpeckers also increased dramatically after correction: Three-toed Woodpecker (five times), Lesser Spotted Woodpecker (three times) and Grey-headed Woodpecker (four times). Being one of the authors of Ottosson et al. (2012), I remember that we had animated discussion about these species. We may have been influenced by the fact that three of the woodpeckers were red-listed in the NT category on the basis of the A criterion (population decline), and therefore unknowingly preferred not to present an estimate that was substantially higher than previously.

The Ortolan Bunting was estimated at 6,000 pairs by Ottvall et al. (2007) and this estimate was accepted by Ottosson et al. (2012). The corrected line transect estimate is much higher, 27,000 pairs. The method used by Ottvall et al. (2007) was similar to the one used here by me in the sense that it was based on the number of birds observed along the lines of the fixed routes of the SBS. But the detectability correction was different, namely an assumption that $75 \%$ of the pairs were detected within $400 \mathrm{~m}$ on both sides of the transect. Lehikoinen et al. (2014) reported $24 \%$ within the $25+25$ meters (the main belt; $n=1431$ pairs) and Rajasärkkä (2010) a corresponding value of $15 \%$ ( $\mathrm{n}=93$ birds). The former estimate gives a KK factor of 5,0 in southern and 5.8 in northern Finland, hence, if applied on the Swedish routes, a population estimate of 20,000 to 30,000 pairs. One cannot exclude that the Finnish correction factors are erroneous for some species. On the other hand, is it realistic that $75 \%$ of all Ortolan bunting pairs within 400 meters from the observer will be recorded during an average line transect by an average observer? Perhaps a more realistic proportion is $25 \%$ ? If so the estimate increases to almost 19,000 pairs, at least approaching the other estimate.

Several of the species in these examples underwent considerable population change during the period 1996-2010. The number of birds per kilometer SBS fixed route that have been used in this paper refers to the average value for that period, and for rapidly declining or increasing species the corresponding value for 2008, the datum year for Ottosson et al. (2012), must have been different. For example, the Rustic Bunting and Ortolan Bunting declined with 70-80 percent between 1996 and 2010 and the Grey-headed Woodpecker increase with about 400 percent according to the SBS indices. Hence, care must be exercised when considering the differences observed between the two estimation methods. Large changes in numbers before 2008 were often accounted for in the estimates by Ottosson et al. (2012). The fixed route data from the same source have not been manipulated in any way before use in this paper. Some of the differences between the two methods may therefore be explained by large population changes. And if such population changes have continued after 2010 the corrected fixed route estimates may be still less valid to-day. New estimates based on the fixed routes for the period after 2010 could have been made. I have not done that because my ambition was to compared data from about the same period as used by Ottosson et al. (2012).

\section{Improved estimates of Swedish bird populations: ideas about what should be done}

It is difficult to guess how long it will take before someone takes the initiative to seriously revise the population estimates in Ottosson et al. (2012). Certain is, however, that for such a revision to be a substantial improvement, new data and new methods must be used. The existing density data (those from territory mapping plots) have been exhausted and are often very old, having been collected in the 1970s to 1990s (pp. 561-567 in Ottosson et al. 2012). In addition, there is no or little present collection of new habitat-specific densities. So even if future habitat maps, for example satellite images, aerial photographs and different scans of the vegetation, will be both sufficiently detailed and possible to interpret in such a way that the habitats are relevant for bird population estimates, it will not be enough. 
Alternative 1: A new scheme for direct determination of absolute densities

The way to do this is obvious. In principle, a network of representative plots must be established all over the country. The most efficient strategy is likely to use stratified random or systematic sampling with more plots in heterogeneous parts of the country and fewer in homogeneous parts. If feasible, the sampling should connect with existing schemes, preferably the joint system of the Breeding Bird Survey and the National Inventory of Landscapes in Sweden (NILS; Ståhl et al. 2011). This would, in addition, potentially provide valuable habitatspecific bird densities for more general extrapolation. The count method must be some form of mapping of territories and, for some species, nests or other breeding cues. The number of visits in a plot will vary, from few in simple, species-poor habitats with a brief and contracted breeding season to several in species-rich habitats with a long collective breeding season. How many years that will be needed for sufficient amount of data to accumulate depends of course on the number of plots that can be surveyed each year, the number of species one aims to cover, and the precision required. This can be calculated as we already know sufficient about both normal densities and normal population variation. Whatever the result of the calculation, such a scheme will be demanding because the mapping method itself is demanding. And as the sample plots must be widely distributed much time will have to be spent travelling. Manpower will be a severely limiting factor even if sufficient funds were made available. And if a high degree of precision is required, a design along the lines described is, although necessary, probably not feasible.

\section{Alternative 2: Application of transformed point and line transect data to estimate absolute numbers}

An enormous number of birds have been counted each year for more than twenty years at points and along lines of the Breeding Bird Survey. Indeed, this program has grown and expanded to become the major instrument for trend monitoring of Swedish birds. It is of course tempting to use those data not only for that purpose but also for population size estimates. This paper is the first effort to do so for a large number of species. The general principle for transformation of relative counts to absolute numbers were laid out in Ottosson et al. (2012) and an equation with the relevant species-specific variables was given: maximum distance for a bird to be recorded, and the probability of recording a male and a female, respectively, within that distance. But the values to put into the equation are not known yet.

As it is not yet established to what extent Finnish conversion factors are applicable in Sweden, it is advisable to develop new factors. To obtain Swedish correction factors the simplest and most realistic way is to establish a number of large plots where population size is determined carefully and completely. Line transects and point counts should then be made in these plots by a variety of people in order to determine average correction factors (sensu Tiainen et al. 1980). Factors that are determined in this way will include both the lateral and basal corrections. A rather small number of such plots, easy to reach but covering all essential habitats, should be established and maintained in a few representative parts of the country. I strongly believe that this is the most efficient way to obtain reliable conversion factors for the point counts and line transects of the Swedish Breeding Bird Survey. An alternative way would be to locate a larger number of smaller mapping plots in connection with a representative sample of fixed routes. Then data from several years of point and line counts would already be available and correction factors would be obtained directly. And if one assumes that the correction factors are independent of details of geography, one could locate the test plots where people, especially volunteers of the same kind as those doing the fixed route counts, are easily available, presuming that all major parts of the country become represented. Both approaches can of course be combined.

\section{Acknowledgement}

Aleksi Lehikoinen informed me about the correction factors for basal detectability. Johan Elmberg and Raimo Virkkala suggested numerous improvements as referees. Without the dedicated volunteers who made the counts along the many hundreds of routes in Finland and Sweden, the national bird surveys as well as this study would not have been possible. My warm thanks go to all of them.

\section{Referenser}

Artdatabanken. 2015. Rödlistade arter i Sverige 2015. Artdatabanken SLU, Uppsala.

Asbirk, S., Berg, L., Hardeng, G., Koskimies, P. \& Petersen, Ae. 1997. Population sizes and trends of birds in the Nordic countries 1978-1994. Tema Nord 1997:614. Nordic Council of Ministers, Copenhagen. 
BirdLife International. 2015. European Red list of Birds. Luxembourg: Office for official publications of the European Communities. DOI: 10.2779/975810.

Enemar, A. 1959. On the determination of the size and composition of a passerine bird population during the breeding season. Vår Fågelvärld, Supplement 2. 114 pp.

Gamero, A., Brotons, L., Brunner, A., Foppen, R., Fornasari, L., Gregory, R. D., Herrando, S., Horak, D., Jiguet, F., Kmecl, P., Lehikoinen, A., Lindström, Å., Paquet, J.-Y., Reif, J., Sirkiä, P. M., Škorpilová, J., van Strien, A., Szép, T., Telenský, T., Teufelbauer, N., Trautmann, S., van Turnhout, C. A. M., Vermouzek, Z., Vikstrøm, T. \& Voříšek, P. 2016. Tracking progress towards EU biodiversity strategy targets: EU policy effects in preserving its common farmland birds. Conservation Letters doi: 10.1111/conl.12292.

Green, M. \& Lindström, Å. 2015. Övervakning av fåglarnas populationsutveckling. Arsrapport för 2014. Dept. Biology, Lund university. (English summary: Monitoring population changes of birds in Sweden. Annual report for 2014).

Järvinen, O. 1976. Estimating relative densities of breeding birds by the line transect method. II. Comparison between methods. Ornis Scandinavica 7: 43-48.

Järvinen, O. 1978. Species-specific census efficiency in line transects. Ornis Scandinavica 9: 164-167.

Järvinen, O. \& Väisänen, R.A. 1975. Estimating relative densities of breeding birds by the line transect method. Oikos 26: 316-322.

Järvinen, O. \& Väisänen, R.A. 1976a. Finnish line transect censuses. Ornis Fennica 53: 115-118.

Järvinen, O. \& Väisänen, R.A. 1976b. Estimating relative densities of breeding birds by the line transect method. IV. Geographical constancy of the proportion of main belt observations. Ornis Fennica 53: 87-91.

Järvinen, O. \& Väisänen, R.A. 1983. Correction coefficients for line transect censuses of breeding birds. Ornis Fennica 60: 97-104.

Järvinen, O., Väisänen, R.A. \& Haila, Y. 1976. Estimating relative densities of breeding birds by the line transect method. III. Temporal constancy of the proportion of main belt observations. Ornis Fennica 53: 40-45.

Järvinen, O., Väisänen, R.A. \& Haila, Y. 1977. Bird census results in different years, stages of the breeding season and times of the day. Ornis Fennica 54: 108-118.

Järvinen, O., Väisänen, R.A. \& Walankiewicz, W. 1978a. Efficiency of the line transect method in central European forests. Ardea 66: 103-111.

Järvinen, O., Väisänen, R.A. \& Enemar, A. 1978b. Efficiency of the line transect method in mountain birch forest. Ornis Fennica 55: 16-23.

Koskimies, P. \& Väisänen, R.A. 1991. Monitoring bird populations. Helsinki university.

Koskimies, P. 1993. Population sizes and recent trends of breeding birds in Nordic countries. Vesi- ja Ympäristöhallitus, Helsinki.

Lehikoinen, A., Honkala, J. \& Sirkiä, P. 2014. Maalintujen alueelliset kannanarviot. [Summary: Regional population estimates for land bird species in Finland] Linnut-Vuosikirja 2014: 68-77.

Lindström, Å., Svensson, S., Green, M. \& Ottvall, R. 2007. Distribution and population changes of two subspecies of Chiffchaff Phylloscopus collybita in Sweden. Ornis Svecica 17: 137-147.
Newson, S.E., Evans, K.L., Noble, D.G., Greenwood, J.J.D. \& Gaston, K.J. 2008. Use of distance sampling to improve estimates of national population sizes for common and widespread breeding birds in the UK. Journal of Applied Ecology 45: 1330-1338.

Ottosson, U., Ottvall, R., Elmberg, J., Green, M., Gustafsson, R., Haas, F., Holmqvist, N., Lindström, Å., Nilsson, L., Svensson, M., Svensson, S. \& Tjernberg, M. 2012. Fåglarna i Sverige - antal och förekomst. Sveriges Ornitologiska Förening, Halmstad.

Ottvall, R., Green, M., Lindström, Å., Svensson, S., Esseen, P.-A. \& Marklund. L. 2008. Distribution and habitat choice of the Ortolan Bunting Emberiza hortulana in Sweden. Ornis Svecica 18: 3-16.

Rajasärkkä, A. 2010. 30 vuotta suojelualueiden linnuston linjlaskentoja. Linnut-Vuosikirja 2010. Birdlife Finland, Helsinki.

Ståhl, G., Allard, A., Esseen, P. et al. 2011. National Inventory of Landscapes in Sweden (NILS) - scope, design, and experiences from establishing a multiscale biodiversity monitoring system. Environmental Monitoring and Assessment 173(1): 579-595. DOI 10.1007/s10661-0101406-7.

Svensson, S. 1996. Svenska häckfågeltaxeringen 1995. Vår Fågelvärld. Supplement nr 25: 11-17.

Svensson, S. 2000. European bird monitoring: geographical scales and sampling strategies. The Ring 22: 3-23.

Tiainen, J., Martin, J.-L., Pakkala, T., Piiroinen, J., Solonen, T., Vickholm, M. \& Virolainen, E. 1980. Efficiency of the line transect and point count methods in a South Finnish forest area. Pp. 107-113 in Bird Census Work and Nature Conservation (H. Oelke, ed.). Dachverbandes Deutscher Avifaunisten.

Ulfstrand, S. \& Högstedt, G. 1976. Hur många fåglar häckar i Sverige? Anser 43: 59-64.

Virkkala, R. \& Lehikoinen, A. 2014. Patterns of climate-induced density shifts of species: poleward shifts faster in northern boreal birds than in southern birds. Global Change Biology 20: 2995-3003.

\section{Sammanfattning}

Tillförlitliga kunskaper om fåglarnas antal behövs inom både internationell och nationell naturvård. Exempelvis har Sverige inom ramen för fågeldirektivet skyldighet att till EU rapportera beståndsstorleken för alla vilda fåglar. Kännedom om beståndsstorleken behövs också för att kunna placera arter i rätt hotkategori vid den så kallade rödlistningen.

I denna uppsats försöker jag förbättra och kontrollera vissa av de skattningar av de svenska fågelbeståndens storlek som gjordes i boken $F a ̊ g-$ larna $i$ Sverige - antal och förekomst (Ottosson m.fl. 2012). I nämnda arbete skedde skattningarna för allmänna arter i de flesta fall med hjälp av biotopspecifika tätheter som multiplicerades med respektive biotops areal. Täthetsuppgifterna hämtades från allehanda källor, men för vanliga 
arter till största delen från de hundratals provytor som inventerades med revirkartering inom Svensk häckfågeltaxering fram till början av 1990-talet. Sådana inventeringar sker numera i mycket ringa omfattning varför uppdaterade och aktuella täthetsskattningar för olika biotoper kommer att saknas för framtida beståndsskattningar.

Jag räknar med att den främsta källan i stället kommer att vara de fasta standardrutterna inom Svensk fågeltaxering. Det finns 716 rutter jämnt spridda över hela landet. Varje rutt är åtta kilometer lång och består av åtta delsträckor om vardera en kilometer och åtta punkträkningar om fem minuter vardera mellan kilometersträckorna. Längs kilometersträckorna räknas alla hörda och sedda fåglar, s.k. linjetaxering. Av flera orsaker kan antalet fåglar som registreras under en sådan linjetaxering inte användas direkt för att beräkna tätheter av antal par. En orsak är att fåglarna registreras oberoende av avståndet, alltså inte inom en given areal. En annan orsak är att vi inte vet hur stor andel av de fåglar som finns som verkligen upptäcks, något som varierar mellan olika arter. En tredje orsak är att fåglarna registreras oberoende av kön, vilket innebär att man inte vet hur många par som de registrerade fåglarna representerar, vilket man givetvis måste veta om man vill beräkna antal par per arealenhet. Det behövs således omräkningsfaktorer, även kallade korrektionsfaktorer, för att använda data från standardrutterna. Sådana faktorer saknas för svenskt vidkommande.

I Finland har man använt linjetaxeringar under lång tid (inventeringsmetodiken beskrivs $\mathrm{i}$ Koskimies \& Väisänen 1991) och där har man tagit fram omräkningsfaktorer. Dessa faktorer kan dock inte utan vidare användas för svenska standardrutter eftersom metoderna skiljer sig i tre avseenden. För det första har man i Finland som räkningsenhet "parekvivalent" (en hane, en hona, ett par, en kull utan förälder) i stället för en individ som på standardrutterna. För det andra registreras fåglarna inom två zoner, inom och utanför 25 meter från linjen. Detta gör det möjligt att beräkna det som kallas lateral upptäckbarhet (detektabilitet). Denna skiljer sig som sagt kraftigt mellan olika arter. Exempelvis är andelen gökar som registreras inom 25 meter lågt i förhållande till andelen kungsfåglar inom samma avstånd. Genom att multiplicera antalet fåglar per kilometer med korrektionsfaktorn för lateral upptäckbarhet blir registreringarna för alla arter jämförbara om än de fortfarande bara är relativa. Men med ytterligare en korrigering kan absoluta täthetsvärden erhållas, nämligen med korrigering för basal upptäckbarhet, dvs. korrigering för fåglar som inte upptäcks alls, inte ens alldeles nära linjen. Korrektionsfaktorer för lateral upptäckbarhet har publicerats av Järvinen \& Väisänen (1983), senare uppdaterade av Lehikoinen (2014) och det är de senare jag använder i denna uppsats. Korrektionsfaktorer för basal upptäckbarhet har publicerats av Rajasärkkä (2010).

Jag har utgått från de värden på antal fåglar som i genomsnitt observerats på standardrutternas linjetaxeringar åren 1996-2010. Dessa värden finns redovisade i tabell A2 på sidorna 552-556 i Ottosson m.fl. 2012). Genom att dividera med längden av en standardrutt, åtta kilometer, har jag fått antalet fåglar som registrerats per kilometer. Därefter har jag multiplicerat med de finska korrektionsfaktorerna för lateral och basal upptäckbarhet och på så sätt fått medelvärden för de olika arternas tätheter (per kvadratkilometer) i Sverige. Dessa medelvärden har därefter multiplicerats med Sveriges areal, 450.000 kvadratkilometer. De på detta sätt erhålla totalvärdena motsvarar dock inte det verkliga antalet par eftersom vi i Sverige räknar individuella fåglar längs standardrutterna medan de finska korrektionsfaktorerna är baserade på räkning av par. Det är för närvarande inte känt på vilket sätt antalet individer motsvarar antalet par.

Jag har därför begränsat analysen till arter för vilka jag anser att majoriteten av registreringarna längs standardrutterna bör motsvara antal par, nämligen för många av de vanliga revirhävdande tättingarna för vilka en sjungande hane kan anses motsvara ett par och för vilka andelen registreringar av annat slag är lågt. Jag har valt 59 arter, de flesta tättingar, men därutöver gök och sex hackspettar. Dessa femtionio arter svarar tillsammans för ungefär 80 procent av alla fåglar i Sverige. Resultatet är sammanfattat i Tabell 1, som inkluderar en jämförelse med skattningarna i Ottosson m.fl. (2012).

För att visa hur de olika fågelarterna påverkas efter korrigering för enbart lateral upptäckbarhet, som är den korrigering där korrektionsfaktorn varierar mest mellan olika arter, visar jag i Figur 1 hur deras rang eller ordningstal förändras. I figuren är arterna ordnade från den vanligaste (överst) till den fåtaligaste enligt de okorrigerade värdena från standardrutternas linjetaxeringar, dvs. enligt nyssnämnda tabell A2 i Ottosson m.fl. (2012). Efter korrigering för arternas olika laterala upptäckbarhet kommer exempelvis göken att förflyttas från rang 15 till rang 39, en förflyttning neråt på hela 24 positioner. Detta är helt naturligt med tanke på hur antalet gökar överskattas på grund av de hörs så långt. Med den tystlåtna grå flugsnapparen är det 
tvärtom. Den flyttas upp 8 positioner i talrikhetsskalan i jämförelse med sin skenbara antalsrankning längs standardrutterna. Att de två vanligaste och de två fåtaligaste arterna inte drabbas av några ändringar är inte förvånande med tanke på att de är så markant vanligare respektive fåtaligare än alla övriga just bland de 59 valda arterna. Några djupare tolkningar kan inte göras utifrån Figur 1 eftersom arterna påverkar varandra ömsesidigt vad gäller position i rangskalan. Figuren visar att det är ungefär samma antal nedgraderingar som uppgraderingar.

I Figur 2 redovisas skattningarna i Ottosson m.fl. (2012) som procent av de korrigerade standardruttsvärdena. I Figur 3 sätts dessa procentvärden i relation till arternas abundans. De talrikaste arterna har skattningar som är ungefär desamma enligt båda metoderna. Däremot är värdena i Ottosson m.fl. (2012) klart lägre än de korrigerade standardruttsvärdena för de fåtaligare arterna. För arter med färre än 100.000 par är $90 \%$ av skattningarna lägre jämfört med $63 \%$ för arter med fler än 100.000 par.

Eftersom detta är det första försöket att använda korrigeringsfaktorer för att omvandla de relativa registreringarna längs standardrutterna till absoluta värden är det viktigt att fråga sig om de finska korrektionsfaktorerna är giltiga för ändamålet. Exempelvis ligger en stor del av Sverige söder om Finland, och Sverige har också mycket mera fjäll än Finland. Man har i Finland funnit att korrektionsfaktorerna varierar från norr till söder, bl.a. som följd av fågelsamhällenas totala tätheter, vilket skulle kunna innebära att omräkningsfaktorerna i södra Sverige kan vara annorlunda än i Finland. Det saknas dock helt studier för att bedöma detta. Däremot kan vi konstatera att de allmänna biotopmässiga förhållandena i Finland och Sverige i de flesta avseenden är ganska likartade, särskilt vad gäller de stora och dominerande arealerna av kommersiella skogar. Det finns därför a priori inga skäl att tro att de finska korrektionsfaktorerna skulle ge drastiskt missvisande resultat om man väljer lämpliga arter, dvs. arter där antalet observationer motsvara antal par.

Att de allra talrikaste arterna har likartade skattningar enligt Ottosson m.fl. (2012) och efter korrigering av standardrutternas linjetaxeringsdata är naturligt. För dessa arter fanns det gott om täthetsdata från nästan alla biotoper och alla delar av landet när beräkningarna gjordes. Det är också väntat att skillnaderna skulle bli större ju färre täthetsdata som fanns tillgängliga, dvs. för de fătaligare arter- na. Men det var inte väntat att skillnaderna mestadels skulle gå i en riktning. Jag kan inte säkert förklara varför skattningarna för fåtaliga arter i Ottosson m.fl. (2012) är lägre än de korrigerade räkningarna från standardrutterna. Eftersom jag själv var med och gjorde beräkningarna och skrev boken minns jag dock de diskussioner som vi hade. De mynnade ofta ut $i$ att vi valde en konservativ och försiktig linje när vi saknade tillräcklig information; vi ville vara på den säkra sidan och inte överskatta bestånden. Jag tror att detta är en väsentlig orsak för flera av underskattningarna.

Eftersom det ännu inte finns några omräkningsfaktorer som gör att standardrutternas relativa täthetsvärden kan omräknas till absoluta tal är det viktigt att diskutera hur totalskattningar av de svenska fågelbestånden ska ske i framtiden. Det finns två sätt att göra detta.

Det ena sättet är att skapa ett nytt system av representativa provytor spridda i olika biotoper över hela landet för att på så sätt få täthetsdata som kan räknas upp till hela Sveriges areal. Eftersom antalet sådana provytor måste vara mycket stort och eftersom de måste karteras flera gånger under en häckningssäsong krävs stora arbetsinsatser och betydande kostnader. Jag bedömer därför att det i praktiken inte är troligt att ett sådant system kommer till stånd.

Det troligaste är, som jag redan framhållit, att standardrutterna inom Svensk fågeltaxering kommer att vara den huvudsakliga källan till kunskap om fågelbestånden, inte bara för tidstrender utan också för skattningar av absoluta beståndsstorlekar. Det andra sättet att skapa totalskattningar av bestånden är därför att experimentellt ta fram omräkningsfaktorer för standardruttsdata. Jag anser att detta bör göras genom att etablera ett mindre antal relativt stora provytor på lämpliga platser i landet. Dessa provytor inventeras sedan så väl att antalet häckande par blir känt med hög noggrannhet. I dessa provytor genomförs sedan punkt- och linjetaxeringar med samma metod som på standardrutterna och av ornitologer som representerar en genomsnittlig standardruttsinventerare. På det sättet får vi direkt omräkningsfaktorer som innefattar både lateral och basal korrigering och som är giltiga för svenska förhållanden. En variant är att förlägga sådana provytor i anslutning till befintliga standardrutter och utnyttja de data som redan insamlats under många tidigare år. En kombination av båda sätten är naturligtvis också möjlig. 